Contacts

Publisher: Ben Crowe

Editor: Paul Smaglik

Marketing Manager: David Bowen

European Head Office,

London

The Macmillan Building

4 Crinan Street

London N1 9XW, UK

Tel +44 (0) 2078434961

Fax +44 (0) 2078434996

e-mail: naturejobs@nature.com

Naturejobs Sales Director

Nevin Bayoumi (4978)

UK/ RoW/ Ireland:

Matt Powell (4953)

Andy Douglas (4975)

Frank Phelan (4944)

Scandinavia/ Spain/ Portugal

Evelina Rubio Håkansson (4973)

Natureevents: Sille Opstrup (4994)

France/ Switzerland:

Amelie Pequignot (4974)

Production Manager: Billie Franklin

To send materials use London

address above.

Tel +44 (0) 2078434814

$\mathrm{Fax}+44$ (0) 2078434996

e-mail: naturejobs@nature.com

Naturejobs web development

Tom Hancock

Naturejobs online production:

Ben Lund

European Satellite Office

Germany/ Austria/ Netherlands/

Italy/Belgium:

Patrick Phelan, Odo Wulffen

Tel + $498954905711 /-2$

Fax +498954905720

e-mail: p.phelan@nature.com o.wulfen@nature.com

US Head Office, New York

345 Park Avenue South

10th Floor, New York, NY 10010-1707

Tel +1 8009897718

Fax +18009897103

e-mail: naturejobs@natureny.com

US Sales Manager: Peter Bless

US Advertising Coordinator

Linda Adam

Japan Head Office, Tokyo

MG Ichigaya Building (5F),

19-1 Haraikatamachi,

Shinjuku-ku,

Tokyo 162-0841

Tel +81332678751

Fax +81332678746

Asia-Pacific Sales Director:

Rinoko Asami

e-mail: rasami@naturejpn.com

\title{
naturejobs
}

\section{Patching a leaky pipeline}

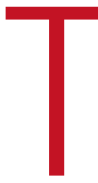

he diagnosis is clear: women are underrepresented in science. And a 'leaky pipeline' means that for those women who do move into this sector, disproportionately fewer of them will rise to the top. Two broad treatments now exist - tackle the symptoms or grapple with the cause. Dealing with the symptoms seems to be easier, but can be less effective. For example, under its Sixth Framework Programme, the European Commission is encouraging academia and industry to hire and promote more women (see Nature 426, $210-211 ; 2003)$. But systems of quotas can cause resentment.

Instead, treating the individual causes - such as women who temporarily step off the tenure ladder to start a family and find it difficult to climb back on - could be a more successful course of action. In the United States, organizations such as the Association for Women in Science (www.awis.org) and philanthropies including the Alfred P. Sloan Foundation (www.sloan.org) have been aggressive in attacking this problem through creative grant schemes.

More recently, European organizations have joined the fray. The European Molecular Biology Organization offers a 'restart' grant, Britain has the Dorothy Hodgkin Fellowships and the Swiss National Science Foundation awards the Marie Heim-Vögtlin grants. These programmes are beginning to yield success stories (see Nature Med. 10, 114-115; 2004).

But they could still be more widespread - encompassing a greater number of countries. And those programmes that do exist in individual countries might be better promoted under a 'European women in science' umbrella. Finally, 'restart' grants, as beneficial as they are, address only one cause of women's underrepresentation in science. Other issues - covert and overt, unintentional or not still exist in institutions in many parts of the world. Addressing them will help more women to enter science, and rise to the top.

\section{Paul Smaglik}

Naturejobs editor

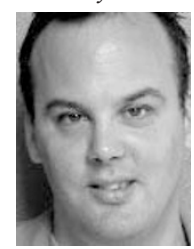

\section{Contents}

\section{REGIONS}

San Francisco's

biotech mission

\section{CAREER VIEW}

Bricks \& Mortar

The Partnership for Structural

Biology

Graduate Journal

Seeking perspective

Movers

William Chia

\section{WWW.NATUREJOBS.COM}

Career centre

Information on the scientific job market

FOCUS

SPOTLIGHT

RECRUITMENT

ANNOUNCEMENTS

EVENTS 